SRR-CWDA-2012-00051

Revision 0

KEYWORDS:

Performance Assessment

FTF

RETENTION: PERMANENT

\title{
Critical Assumptions in the F-Tank Farm Operational Closure Documentation Regarding Waste Tank Internal Configurations
}

March 28, 2012

Prepared by: Savannah River Remediation LLC

Closure and Waste Disposal Authority

Aiken, SC 29808 


\section{APPROVALS}

Author:

Steve Hommel

Date

Closure \& Waste Disposal Authority

Navarro Research and Engineering Associates

Technical Reviews:

Mark Layton (Checked per ENG.51)

Date

Closure \& Waste Disposal Authority

Savannah River Remediation

Rudolph Jolly

Date

Closure Engineering

Savannah River Remediation

Management Reviews:

Mark Mahoney

Date

Manager, Closure \& Waste Disposal Authority, Determinations

Savannah River Remediation

Kent Rosenberger

Date

Manager, Closure \& Waste Disposal Authority, Assessments

Savannah River Remediation 


\section{TABLE OF CONTENTS}

TABLE OF CONTENTS................................................................................................... ii

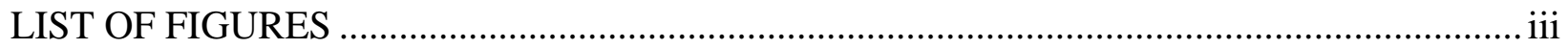

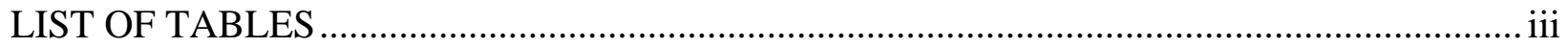

ACRONYMS/ABBREVIATIONS............................................................................ iv

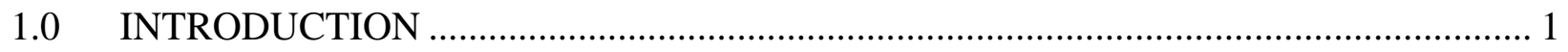

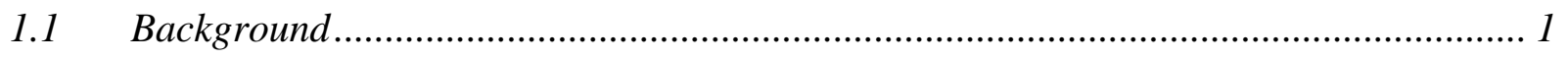

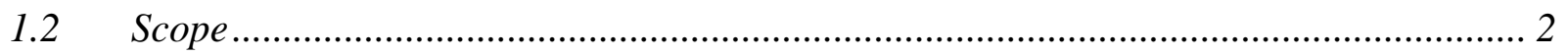

$2.0 \quad$ PRACTICALITY OF COMPONENT GROUTING ................................................... 3

3.0 GROUTING PROCESSES AND CONFIGURATIONS .......................................... 5

3.1 Waste Tank Grouting Strategy ........................................................................... 5

3.2 Plans for Grouting Remnant Artifacts Within Waste Tanks ...................................... 8

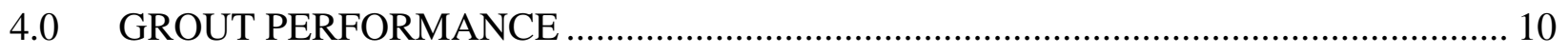

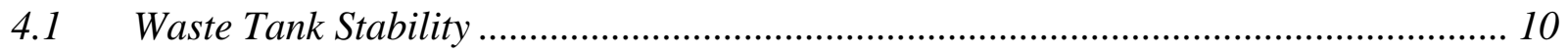

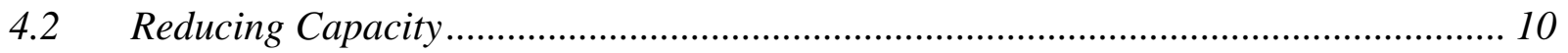

4.2.1 Tank 18/Tank 19 Remnant Artifact Impact on Grout Reducing Capacity ............. 11

4.2.2 Cooling Coil Volume Considerations .............................................................. 13

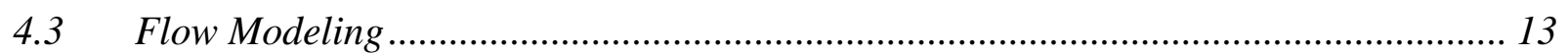

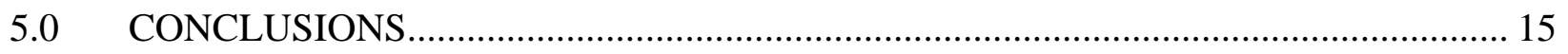

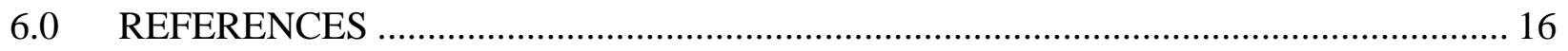




\section{LIST OF FIGURES}

Figure 3.1-1: Typical Tank 18 and 19 Grouting Configuration................................................ 6

Figure 4.3-1: Tank Configuration D .................................................................................. 14

\section{LIST OF TABLES}

Table 3.1-1: Mechanical and Chemical Properties for Grout Material ...................................... 7

Table 3.2-1: General Plan for Remnant Artifacts and Materials within Waste Tanks ................ 9

Table 4.2-1: Estimates for Volume Displaced by Equipment to Remain within Tank 18 .......... 11

Table 4.2-2: Estimates for Volume Displaced by Equipment to Remain within Tank 19 .......... 12

Table 4.2-2: Displaced Volume Estimates for Cooling Coils in Select Waste Tank Types........ 13

Table 5.0-1: Matrix of Impact Assessments for Remnant Artifacts in Waste Tanks ................. 15 


\section{ACRONYMS/ABBREVIATIONS}

\begin{tabular}{|l|l|}
\hline ADMP & Advanced Design Mixer Pump \\
\hline CZ & Contamination Zone \\
\hline FTF & F-Tank Farm \\
\hline PA & Performance Assessment \\
\hline
\end{tabular}




\subsection{INTRODUCTION}

The intent of this document is to provide clarification of critical assumptions regarding the internal configurations of liquid waste tanks at operational closure, with respect to F-Tank Farm (FTF) closure documentation. For the purposes of this document, FTF closure documentation includes:

1. Performance Assessment for the F-Tank Farm at the Savannah River Site (hereafter referred to as the FTF PA) (SRS-REG-2007-00002),

2. Basis for Section 3116 Determination for Closure of F-Tank Farm at the Savannah River Site (DOE/SRS-WD-2012-001),

3. Tier 1 Closure Plan for the F-Area Waste Tank Systems at the Savannah River Site (SRR-CWDA-2010-00147),

4. F-Tank Farm Tanks 18 and 19 DOE Manual 435.1-1 Tier 2 Closure Plan Savannah River Site (SRR-CWDA-2011-00015),

5. Industrial Wastewater Closure Module for the Liquid Waste Tanks 18 and 19 (SRRCWDA-2010-00003), and

6. Tank 18/Tank 19 Special Analysis for the Performance Assessment for the F-Tank Farm at the Savannah River Site (hereafter referred to as the Tank 18/Tank 19 Special Analysis) (SRR-CWDA-2010-00124).

Note that the first three FTF closure documents listed apply to the entire FTF, whereas the last three FTF closure documents listed are specific to Tanks 18 and 19. These two waste tanks are expected to be the first two tanks to be grouted and operationally closed under the current suite of FTF closure documents and many of the assumptions and approaches that apply to these two tanks are also applicable to the other FTF waste tanks and operational closure processes.

\subsection{Background}

Residual contaminants will be stabilized by filling waste tanks with grout after the removal of waste. Grout is a mixture of primarily cement and water that is proportioned to produce a pourable consistency and hardens over time. Grout is commonly used to solidify and stabilize radioactive wastes and the technology is at a mature stage of development. Stabilization with grout maintains the waste tank structure and minimizes water infiltration over an extended period of time, thereby impeding the release of stabilized contaminants into the environment. [DOE/SRS-WD-2012-001]

FTF closure activities will use reducing grout, with low reduction potential (Eh), thus minimizing the mobility of the radionuclides after closure. All grout formulas are alkaline because grout is a cement-based material that naturally has a high $\mathrm{pH}$ which is compatible with the carbon steel waste tank liner. The tank fill grout will have high compressive strength and low permeability, enhancing its ability to limit the migration of contaminants after closure. [SRSREG-2007-00002]

In preparing waste tanks for operational closure, due diligence will be used to: 
1. Prevent additional non-grout materials from entering the waste tanks prior to operational closure and

2. Attempt to grout components with fillable void spaces, such as abandoned pumps.

Despite this due diligence, it is expected that some remnant artifacts may be emplaced within the waste tanks and that some components will have voids remaining after grouting. The presence of such remnant artifacts has been discussed within the FTF closure documents. [SRR-CWDA2010-00003, DOE/SRS-WD-2012-001]

The conceptual models supporting the FTF closure documents did not explicitly model the presence of remnant artifacts within the grouted tanks at operational closure with the implicit understanding that such non-homogeneities within the grouted waste tanks would be negligible (i.e., they would not appreciably impact grout performance with respect to waste tank stability, flow through the contamination zone (CZ), or the reducing capacity of the grout). [SRS-REG2007-00002, SRR-CWDA-2010-00124]

\subsection{Scope}

This document (1) evaluates the expected impacts of remnant artifacts left within waste tanks at the time of operational closure and (2) clarifies the difference between negligible impacts from these remnant artifacts and what should be considered changes to waste tank closure configurations. Section 2 discusses a relevant interaction (clarifying comment and response) between the United States Department of Energy and the United States Nuclear Regulatory Commission, with respect to grouting these remnant artifacts. Section 3 of this document describes the grouting processes and proposed strategies based on the FTF closure documents. Section 4 of this document describes assumptions from the FTF closure documents relevant to the future performance of grout given the presence of remnant artifacts. Section 5 summarizes the conclusions from these discussions. 


\subsection{PRACTICALITY OF COMPONENT GROUTING}

In a clarifying comment (CC-WD-2) during consultation interactions, the United States Nuclear Regulatory Commission noted that in the FTF Waste Determination document, the United States Department of Energy indicated that various pieces of equipment in both the primary tanks and the annulus will be grouted to the extent practical. [SRR-CWDA-2011-00054] The United States Nuclear Regulatory Commission questioned the criteria for determining "the practicality of component grouting." [SRR-CWDA-2011-00054] Briefly, the Nuclear Regulatory Commission's clarifying comment asks:

(1) What remnant artifacts will be grouted?

(2) For materials that won't be grouted, why isn't grouting practical?

(3) What is the potential impact of the items that are not grouted?

[SRR-CWDA-2011-00054]

The response to this clarifying comment is relevant to the content of this document with respect to waste tank configurations and the grouting of remnant artifacts. The United States Department of Energy answered:

"The intent of the in-tank equipment grouting process using highly flowable grout is to eliminate fast flow paths that would potentially be present due to void spaces in equipment that extend vertically from the waste tank top down through the grouted waste tank. The configuration of the grouted waste tank, annulus and equipment is intended to eliminate fast flow paths (i.e., significant vertical voids that provide a pathway for infiltrating water to bypass the grout layer and impact the contaminant zone) and be consistent with the Base Case (Configuration A) presented in the FTF PA.”

[SRR-CWDA-2011-00054]

In the response, the United States Department of Energy proposes general plans for the handling of remnant artifacts within waste tanks at the time of operational closure. The following summarizes the proposed approach:

(1) Equipment to be entombed in the grouted waste tank will be identified and documented.

(2) Modifications to equipment will be performed (from the waste tank top) to provide access to deliver grout to the void spaces of equipment that will be entombed in the grouted waste tank.

(3) Equipment that extends to the tank top will have its void spaces filled with grout directly.

(4) Equipment that does not extend to the tank top will have its voids grouted indirectly through encapsulation.

(5) Efforts will be made to assess the completeness of filling equipment void spaces.

[SRR-CWDA-2011-00054] 
The United States Department of Energy's response also provided some relevant assumptions with respect to the disposition of various potential remnant artifacts:

(1) Small equipment such as sample crawlers have minimal void spaces and grout will generally flow into horizontal spaces.

(2) The use of a highly flowable grout will maximize the ability to fill voids in equipment in the waste tanks at operational closure.

a. For example, observation of simulated cooling coil test samples indicated that air entrainment and resulting void space was much less than $4 \%$.

(3) The void spaces of some equipment that do not extend to the top of the waste tank cannot be fully grouted.

a. Void space grouting may be limited by inadequate grout delivery access to transfer pumps located at various elevations within waste tanks.

b. Void spaces of entombed equipment that do not extend to the top of the waste tank do not provide a vertical void space of significant length to create a fast flow path through the grouted tank.

c. Because this equipment does not provide a vertical void space of significant length to provide a fast flow path, these would not invalidate the Base Case configurations of the FTF PA.

[SRR-CWDA-2011-00054] 


\subsection{GROUTING PROCESSES AND CONFIGURATIONS}

The United States Department of Energy issued an Environmental Impact Statement on waste tank cleaning and stabilization alternatives in 2002. [DOE-EIS-0303] The Department of Energy studied a number of alternatives and concluded that filling the waste tanks with grout was the preferred option for waste tank stabilization. [DOE-EIS-0303 ROD]

Filling a cleaned waste tank with grout prevents the walls and ceiling from possible collapse thereby providing long-term stability. The grout fill also helps to reduce water intrusion into the waste tank over time. Reducing the amount of water entering a closed waste tank retards the migration of residual materials from the waste tank to the environment. Testing has demonstrated that the chemical and physical characteristics of the grout formula used at the Savannah River Site retards the movement of chemical constituents. [WSRC-TR-97-0102]

Independent testing determined that certain formulas of grout provide a superior protection for any stabilized contaminant that might remain in the waste tank. [WSRC-STI-2007-00369] The fill grout that will be used at the FTF has reducing properties (i.e., low redox or Eh) which minimize the mobility of the chemicals after operational closure. All grout formulas are alkaline because grout is a cement-based material that naturally has a high $\mathrm{pH}$. This alkalinity is compatible with the carbon steel materials of construction of the waste tank. Grout has a high compressive strength and low permeability, which enhances its ability to limit the migration of contaminants after operational closure. The grout formulas are also designed to promote flowability, thereby enabling a near level placement within the waste tank. [SRS-REG-200700002]

\subsection{Waste Tank Grouting Strategy}

The following text describes the approach for grouting Tanks 18 and 19 (from Section 7 of the Industrial Wastewater Closure Module for the Liquid Waste Tanks 18 and 19). [SRR-CWDA2010-00003] These tanks are expected to be the first to be grouted and operationally closed under current FTF closure documentation. Although this grouting strategy is specific to Tanks 18 and 19, many of the assumptions and approaches are applicable to the grouting and operational closure of other FTF waste tanks.

Each waste tank riser will be filled with grout through the lower sections of each riser. Additional details on the isolation of the waste tank mechanical, electrical, equipment, and piping systems from service are presented in the Tank 18 Closure Isolation Plan [M-CTP-F00003] and the Tank 19 Closure Isolation Plan. [M-CTP-F-00004]

For Type IV waste tanks, placement of the grout can be through risers in each quadrant of the waste tank and/or the center riser. [WSRC-RP-2005-01684] Figure 3.1-1 illustrates the typical grouted configuration for Tanks 18 and 19 (shown with potential earthen cover). 
Figure 3.1-1: Typical Tank 18 and 19 Grouting Configuration

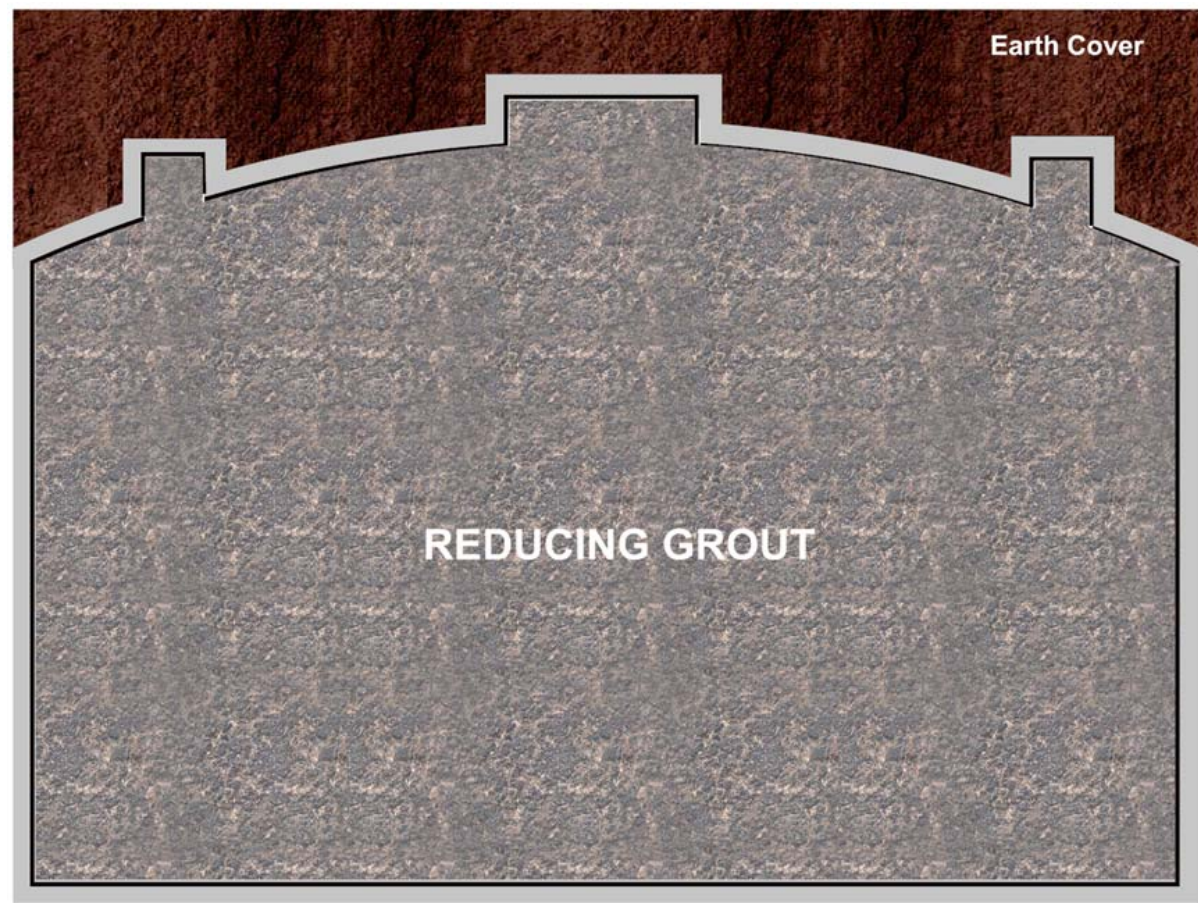

Reducing grout will be used to fill the entire volume of Tanks 18 and 19. Reducing grout is composed primarily of cement, sand, water, fly ash, slag, silica fume, and other additives. The reducing grout mix must be flowable, pumpable, and self-leveling to minimize void space formation. Table 3.1-1 outlines some of the nominal specifications for the grout that will be used to support the removal from service activities. [SRR-LWE-2010-00318] 
Table 3.1-1: Mechanical and Chemical Properties for Grout Material

\begin{tabular}{|c|c|}
\hline Properties & Engineering Specifications \\
\hline \multicolumn{2}{|l|}{ I. Fresh Properties } \\
\hline Slump Flow & $24 \pm 4$ inches \\
\hline Air Content & $<8$ percent volume \\
\hline Unit Weight & $132 \pm 2$ pounds per cubic foot \\
\hline Set Time & $<24$ hours \\
\hline Bleed Water & $<0.5$ percent volume after 24 hours \\
\hline Max temperature after placement & 65 degrees Celsius \\
\hline Slurry pH & $>12.4$ (unitless) \\
\hline \multicolumn{2}{|l|}{ II. Cured Properties from FTF PA } \\
\hline Hydraulic Conductivity & $<3.6 \mathrm{E}-08$ centimeters per second \\
\hline Compressive Strength & $>2,000$ pounds per square inch at 90 days \\
\hline Porosity & $<26.6$ percent \\
\hline Dry Bulk Density & 1.81 grams per cubic centimeter \\
\hline Particle Density & 2.51 grams per cubic centimeter \\
\hline Effective Diffusion Coefficient & 8.00E-07 square centimeters per second \\
\hline $\begin{array}{l}\text { Water Retention and van Genuchten Parameters } \\
\text { to characterize unsaturated moisture transport }\end{array}$ & $\begin{array}{l}\text { Van Genuchten Parameters same as parameters } \\
\text { used in FTF PA }\end{array}$ \\
\hline High Reducing Capacity (negative Eh) & $>210$ pounds of slag per cubic yard \\
\hline $\begin{array}{l}\text { High Alkalinity (based on } \mathrm{Ca}(\mathrm{OH}) 2 \text { and Calcium } \\
\text { leaching / carbonation) }\end{array}$ & > 75 pounds of Portland cement per cubic yard \\
\hline
\end{tabular}

[SRR-LWE-2010-00318]

Most grout types consist of two major states, cured and fresh. [WSRC-STI-2007-00369] The major specifications for cured properties of grout include compressive strength, effective diffusion coefficient, hydraulic conductivity, porosity, dry bulk density, and Young's Modulus. The fresh grout properties include flow, bleed water generation, set time, air content, and wet unit weight (density). [WSRC-STI-2007-00641] The quality control of the grout production will be included as part of the grout procurement specification. [C-SPP-F-00055]

The waste tank risers will be modified as needed to permit grout to be placed into the waste tank. Video cameras will be used during the grout pouring process to monitor for potential void space formations. To completely fill the tank risers with grout, an alternate grout mix that does not affect the tank modeling but is easier to mix and pump from a smaller system may be utilized. The alternative mix will also not have an effect on the bulk reducing grout. Once the risers are filled, they are capped with the reducing grout mix. Provisions will be made to provide delivery 
points into the waste tank, to manage air displacement, to address bleed water build-up, and to handle any waste tank top overflow. The waste tank will be ventilated until after grouting is complete. Final grouted tank configurations for waste tanks will be reported in the applicable Final Configuration Reports.

\subsection{Plans for Grouting Remnant Artifacts Within Waste Tanks}

As previously stated, remnant artifacts are anticipated to either be present in, or have the potential to be added to, the FTF waste tanks prior to grouting. In addition to grouting the void spaces, "large pieces of equipment ... will be entombed in place with grout and connected to the risers in which they are located" as is consistent with approach described in Section 7.2 of the Industrial Wastewater Closure Module for the Liquid Waste Tanks 18 and 19). [SRR-CWDA2010-00003] Smaller items are generally considered negligible with respect to post closure performance of the waste tank grout.

Table 3.2-1 lists examples of potential remnant artifacts and materials that may be present at the time of operational waste tank closure and provides preliminary recommendations with respect to grouting such items. Regardless of these preliminary recommendations, the final grouted tank configurations for each waste tank will be considered independently and documented within applicable Final Configuration Reports.

Results from mock up testing to address placement issues associated with grouting the equipment that will be left in Tanks 18 and 19 have successfully demonstrated the filling of mock up forms (ADMP form and one and two inch inner-diameter pipes) by gravity filling. Based on these tests, a mix suitable for gravity filling the ancillary equipment geometries and pipe geometries down to at least a one inch diameter was identified. The grout mixes used in these tests were consistent with the cured grout properties assumed in the FTF PA. [SRNL-STI2011-00564, SRNL-STI-2011-00592] 
Critical Assumptions in the FTF Operational

Table 3.2-1: General Plan for Remnant Artifacts and Materials within Waste Tanks

\begin{tabular}{|c|c|}
\hline $\begin{array}{l}\text { Examples of Remnant } \\
\text { Artifacts/Materials }\end{array}$ & Expected Final Dispositions Actions \\
\hline $\begin{array}{l}\text { Water (Rain, Flush and/or Bleed } \\
\text { Water) }\end{array}$ & $\begin{array}{l}\text { Expected to mix with the fill grout during pouring, providing a } \\
\text { negligible impact to the grout mixture. No action. }\end{array}$ \\
\hline Cooling Coils & Fill with grout to the extent practical. Encapsulate in grout. \\
\hline Mantis & Not accessible to grout/minimal void space. Encapsulate in grout. \\
\hline Robotic Crawler & Not accessible to grout/minimal void space. Encapsulate in grout. \\
\hline $\begin{array}{l}\text { Sampling Mast and Other } \\
\text { Sampling Tools }\end{array}$ & $\begin{array}{l}\text { Fill interior space and/or piping with grout (if accessible) to the extent } \\
\text { practical. Encapsulate in grout. }\end{array}$ \\
\hline Flygt Mixers & No interior spaces. Encapsulate in grout. \\
\hline ADMP & $\begin{array}{l}\text { Fill interior space with grout to the extent practical. Encapsulate in } \\
\text { grout. }\end{array}$ \\
\hline Standard Mixer Pumps & $\begin{array}{l}\text { Fill interior space with grout to the extent practical. Encapsulate in } \\
\text { grout. }\end{array}$ \\
\hline Evaporator Feed Pumps & $\begin{array}{l}\text { Fill piping, hoses, and eductors with grout (if accessible) to the extent } \\
\text { practical. Pump entombed pillbox above riser. Encapsulate in grout. }\end{array}$ \\
\hline Transfer Pumps/Jets & $\begin{array}{l}\text { Fill interior space and/or piping with grout (if accessible) to the extent } \\
\text { practical. Encapsulate in grout. }\end{array}$ \\
\hline Thermowells & $\begin{array}{l}\text { Fill interior space and/or piping with grout (if accessible) to the extent } \\
\text { practical. Encapsulate in grout. }\end{array}$ \\
\hline $\begin{array}{l}\text { Backfill/Grout Piping (including } \\
\text { tremies }^{\text {b }} \text { ) }\end{array}$ & $\begin{array}{l}\text { Fill interior space and/or piping with grout (if accessible) to the extent } \\
\text { practical. Encapsulate in grout. }\end{array}$ \\
\hline Clean Out Balls & Small items/minimal void space. No action. \\
\hline $\begin{array}{l}\text { Other Hoses, Cables, Steel } \\
\text { Tapes }\end{array}$ & Small items/minimal void space. No action. \\
\hline Other Pumps, Jets, and Mixers & $\begin{array}{l}\text { Fill interior space and/or piping with grout (if accessible) to the extent } \\
\text { practical. Encapsulate in grout. }\end{array}$ \\
\hline $\begin{array}{l}\text { Level Instrumentation (Dip } \\
\text { Tube Assembly) }\end{array}$ & $\begin{array}{l}\text { Fill interior space and/or piping with grout (if accessible) to the extent } \\
\text { practical. Encapsulate in grout. }\end{array}$ \\
\hline Miscellaneous (small items) ${ }^{\mathrm{c}}$ & Small items/minimal void space. Encapsulate within the grout. \\
\hline
\end{tabular}

Notes: (a) This list was developed from information provided in SRR-CWDA-2010-00003, SRR-LWE-2010-00175, and SRR-CWDA-2011-00054.

(b) A tremie is a pipe used to convey and deposit grout rather than pouring the material from a height.

(c) Includes items such as personal protective equipment, tape, plastic sheeting, hand tools, and sample vials. 


\subsection{GROUT PERFORMANCE}

The FTF closure documents contain assumptions regarding the waste tank grout's performance with respect to:

- Stability

- Grout reducing capacity

- Flow through the CZ

These grout performance topics and their implications with respect to assumed performance are addressed in additional detail below.

\subsection{Waste Tank Stability}

Section 3.2.1.5 of the FTF PA states that "the entire tank is assumed to be filled with grout, therefore structural failure (i.e., collapse) is not considered." In addition, Section 4.4.1 of the FTF PA asserts that "[g]routing of tank void areas (e.g., waste tank primary, tank annulus, cooling coils) is assumed to have occurred as planned." [SRS-REG-2007-00002] The Basis for Section 3116 Determination for Closure of F-Tank Farm at the Savannah River Site states that, along with the waste tank, "the cooling coils and annulus will be grouted to minimize void spaces, to minimize fast flow pathways and for stability. Annulus risers and ductwork will be filled with grout up to grade level and closed and capped.” [DOE/SRS-WD-2012-001]

The flowability of the grout formula (described in Section 3.1, above) and the due diligence in attempting to fill void spaces (described in Sections 2.0 and 3.2, above), coupled with the assumptions provided in the United States Department of Energy's response to clarifying comment CC-WD-2 (as described in Section 2.0, above), provide confidence that the presence of remnant artifacts will not significantly impact the stability of the grouted waste tanks.

\subsection{Reducing Capacity}

The FTF PA and the Tank 18/Tank 19 Special Analysis models assume that the reducing capacity of the fill grout changes as a function of pore volume flushing. [SRS-REG-2007-00002, SRR-CWDA-2010-00124] Once enough water flows through the pore volumes of the grouted waste tank, these models assume that the fill grout properties instantly transition from reducing to oxidizing.

Specifically, the grout transitions from reducing to oxidizing after 371 pore volume flushes (per the FTF PA) or 523 pore volume flushes (per the Tank 18/Tank 19 Special Analysis). [SRRCWDA-2010-00124] For Type IV waste tanks, these pore volume flushes translate into transition times of 10,456 or 12,371 years after closure, respectively, for Type IV waste tanks. Because the timing of these transitions is determined based on pore volume space, the relative impact on the reducing capacity of the grout from materials left within a waste tank may be estimated based on the volume of grout displaced.

As an example, the following analysis (in Section 4.2.1, below) evaluates the impacts of remnant artifacts that will be entombed within Tanks 18 and 19. 


\subsubsection{Tank 18/Tank 19 Remnant Artifact Impact on Grout Reducing Capacity}

Based on the isolation plans for Tanks 18 and 19, the Industrial Wastewater Closure Module for the Liquid Waste Tanks 18 and 19 defined a number of remnant artifacts that will be entombed within Tanks 18 and 19 upon operational closure. [SRR-CWDA-2010-00003] The external volumes of these remnant artifacts have been estimated in Tables 4.2-1 and 4.22 , below. These volume estimates shall be used to estimate potential volume of grout that would be displaced by the presence of such equipment and the impacts relative the pore volume flushes and reducing capacity of the grout.

Table 4.2-1: Estimates for Volume Displaced by Equipment to Remain within Tank 18

\begin{tabular}{|l|l|c|c|}
\hline Equipment & Description & Qty & $\begin{array}{c}\text { Estimated } \\
\text { Volume } \\
\text { a,ballons) }\end{array}$ \\
\hline $\begin{array}{l}\text { ADMP (Center } \\
\text { riser) }\end{array}$ & $\begin{array}{l}\text { Advanced design mixer pump is a 45 feet long by 22 inch } \\
\text { diameter vertical shaft (SRR-CWDA-2010-00003) }\end{array}$ & 1 & 889 \\
\hline $\begin{array}{l}\text { Transfer Pump } \\
\text { (Northeast Riser) }\end{array}$ & $\begin{array}{l}\text { 40 inches long by 22 inch diameter pump (C-CLC-F- } \\
\text { 00462) }\end{array}$ & 1 & 66 \\
\hline $\begin{array}{l}\text { Transfer Pump } \\
\text { (West Riser) }\end{array}$ & $\begin{array}{l}40 \text { inches long by 22 inch diameter pump (C-CLC-F- } \\
\text { 00462) }\end{array}$ & 1 & 66 \\
\hline Transfer Pump Pipes & $\begin{array}{l}\text { Pumps are hanging from 45 foot long by 2.5 inch diameter } \\
\text { pipe (C-CLC-F-00462) }\end{array}$ & 2 & 23 \\
\hline $\begin{array}{l}\text { Standard Mixer } \\
\text { Pumps }\end{array}$ & $\begin{array}{l}\text { 45 feet long by 22.5 inch diameter (Figure 3.1-6 of SRR- } \\
\text { CWDA-2010-00003) }\end{array}$ & 2 & 1859 \\
\hline Dewatering Pump & $\begin{array}{l}\text { 19 inches long by 7.5 inch diameter with flexible } \\
\text { discharge hoses (FTF-TMC-02-015) }\end{array}$ & 1 & 4 \\
\hline $\begin{array}{l}\text { Evaporator feed } \\
\text { pump }\end{array}$ & Pump is 5.67 feet long by 20 inch diameter (S5-2-2489) & 1 & 734 \\
\hline Sampling Mast & Mast is estimated as 45 feet long by 20 inch diameter & 1 & 734 \\
\hline Mantis & $\begin{array}{l}\text { Robotic crawler with high pressure eductor approximately } \\
\text { 3 feet long by 2 feet wide (SRR-CWDA-2010-00003). } \\
\text { The rest of the mantis is not defined. }\end{array}$ & 1 & 22 \\
\hline $\begin{array}{l}\text { Robotic crawler } \\
\text { (sampling) }\end{array}$ & Dimensions not defined. \\
\hline $\begin{array}{l}\text { Transfer lines } \\
\text { (various lengths) }\end{array}$ & $\begin{array}{l}\text { 3-inch diameter stainless steel inlet and outlet transfer } \\
\text { lines and 4-inch diameter transfer lines. }\end{array}$ & 1 & Undefined \\
\hline
\end{tabular}

Notes: (a) Volumes estimated in cubic inches, then converted into gallons using 1 cubic inch $=0.004329$ gallons.

(b) Volumes provided are total volumes (i.e., quantity times the estimated unit volume) for the identified equipment. For example, the estimated volume of a standard mixer pump was approximately 929.5 gallons $(929.5 \times 2=1859)$. 
Table 4.2-2: Estimates for Volume Displaced by Equipment to Remain within Tank 19

\begin{tabular}{|c|c|c|c|}
\hline Equipment & Description & Qty & $\begin{array}{l}\text { Estimated } \\
\text { Volume } \\
\text { (gallons) } \\
\end{array}$ \\
\hline Transfer Jet & $\begin{array}{l}45 \text { feet long by } 22 \text { inch diameter jet tubing and casing } \\
\text { (DPSP-84-17-7) }\end{array}$ & 1 & 889 \\
\hline Thermowell & $\begin{array}{l}45 \text { feet long by } 2 \text { inch diameter stainless steel pipe (DPSP- } \\
84-17-7)\end{array}$ & 1 & 7 \\
\hline Dip Tube Assembly & 43 feet 4 inches long by 4 inch diameter (D179154) & 1 & 28 \\
\hline $\begin{array}{l}\text { BIBO Dewatering } \\
\text { Pump }\end{array}$ & Maximum 25.75 inches long by 15.5 inch diameter & 1 & 21 \\
\hline Dewatering Pump & 19 inches long by 7.5 inch diameter (FTF-TMC-02-015) & 1 & 4 \\
\hline $\begin{array}{l}\text { Pitbull Transfer } \\
\text { Pump }\end{array}$ & $\begin{array}{l}49 \text { inches tall by } 14 \text { inch diameter cylindrical pump } \\
\text { (PNNL-11968) }\end{array}$ & 1 & 33 \\
\hline Flygt Mixers & $\begin{array}{l}\text { Submersible jet mixer pumps approximately } 3 \text { feet long by } \\
22 \text { inch diameter }\end{array}$ & 3 & 178 \\
\hline Transfer Pump Pipes & $\begin{array}{l}\text { Attached to a } 45 \text {-foot long by } 22 \text { inch diameter rotating } \\
\text { mast (PNNL-12168) }\end{array}$ & 3 & 2666 \\
\hline Mantis & $\begin{array}{l}\text { Robotic crawler with high pressure eductor approximately } \\
3 \text { feet long by } 2 \text { feet wide (SRR-CWDA-2010-00003). } \\
\text { The rest of the mantis is not defined. }\end{array}$ & 1 & 22 \\
\hline
\end{tabular}

Notes: (a) Volumes estimated in cubic inches, then converted into gallons using 1 cubic inch $=0.004329$ gallons.

(b) Volumes provided are total volumes (i.e., quantity times the estimated unit volume) for the identified equipment. For example, the estimated volume of a Flygt mixer pump was approximately 59.2 gallons $(59.2 \times 3=177.6)$.

Based on these values, the estimated total volumes for the equipment remaining in Tanks 18 and 19 will be 4,397 gallons and 3,848 gallons, respectively. To account for the volumes of the transfer lines, hoses, and other undefined materials, the following analysis applies a conservative assumption that the total volume of grout displaced by equipment in each tank will be no more than 6,000 gallons.

Using the more conservative assumptions for pore volume transition timings (i.e., using 371 pore volume flushes instead of 523), and the assumption of 6,000 gallons displaced, the transition timing for Tanks 18 and 19 moves from 10,456 years after closure to 10,388 years after closure. This is an insignificant timing change with respect to the time periods considered and occurs after the 10,000-year performance period; therefore, changes to reducing capacity from the materials left within the waste tanks are not expected to impact results relative to performance objectives defined in the FTF PA. [SRS-REG-2007-00002]

Modifying this calculation, it was estimated that for a Type IV waste tank more than 40,000 gallons of grout would need to be displaced by the presence of remnant artifacts in order for 
the transition of reducing to oxidizing to occur significantly sooner (e.g., within the 10,000year performance period). The other FTF waste tank types (i.e., Types I, III, and IIIA) have later grout transition times, so it is expected that a larger volume of remnant artifacts would be necessary to displace enough grout for these transition times to occur within the performance period. For conservatism, it is recommended that half this volume (i.e., 20,000 gallons) be permitted within each waste tank before additional evaluations are considered. Regardless of this recommended threshold of 20,000 gallons, it is noted that due diligence should be exercised to limit the volume of remnant artifacts and materials (as is practical) to ensure that a minimum volume of grout is displaced.

\subsubsection{Cooling Coil Volume Considerations}

It is important to note the presence of cooling coils within the other FTF waste tank types (i.e., Types I, III, and IIIA). Table 4.2-2 provides the estimated volumes of space displaced by these cooling coils. Adding these volumes to the conservative 6,000 gallon estimate applied in the Tank 18 and Tank 19 example (see Section 4.2.1) results in volume estimates that are within the 20,000 gallon configuration thresholds.

\section{Table 4.2-2: Displaced Volume Estimates for Cooling Coils in Select Waste Tank Types}

\begin{tabular}{|c|c|c|}
\hline Tank Type & $\begin{array}{c}\text { Displaced Volume Estimate } \\
\text { (gallons) }^{\mathbf{a}}\end{array}$ & Reference \\
\hline Type I & 5,243 & C-CLC-G-00364 \\
\hline Type II & 6,762 & C-CLC-G-00364 \\
\hline Type III & 2,080 & M-CLC-H-02820 \\
\hline Type IIIA & 3,658 & M-CLC-H-02820 \\
\hline
\end{tabular}

Notes: (a) When multiple cooling coil volume estimates were available (e.g., if there was more than one cooling coil configuration) the highest volume was selected to ensure conservatism.

\subsection{Flow Modeling}

Section 4.4.1 of the FTF PA provides a description of waste tank modeling, acknowledging that the grout within each waste tank was modeled as a discrete modeled area, ignoring the presence of interior objects (such as cooling coils and support columns). A number of different tank configurations were modeled within the PA using PORFLOW to determine various flow scenarios through the FTF closure system. [SRS-REG-2007-00002] The presence of remnant artifacts is not expected to have a significant impact on flow; therefore the validity of the Base Case flow model is not compromised by these materials.

Regardless, the "fast flow" model of FTF PA (i.e., alternate waste tank Configuration D) allows for evaluation of the effects of a preferential flow path that channels flow from the tank roof to the CZ. This alternative configuration may be loosely interpreted as a conservative representation of the effects of a remnant artifact that has the requisite shape, placement, and void space to direct flow into the $\mathrm{CZ}$ and out of the bottom of the waste tank. 
To represent the effect of a hypothetical fast flow path through a waste tank, the PORFLOW model assumed all water being shed from the tank roof was intercepted by a high conductivity vertical leg encircling the tank perimeter just inside the primary liner. [SRS-REG-2007-00002] Horizontal flow then takes place through the $\mathrm{CZ}$, which is also assigned a large conductivity, with the entire CZ assumed to be contacted by infiltrating water (see Figure 4.3-1). Contaminant transport was then assumed to take place through a high conductivity hole in the waste tank basemat that allowed full flow through the fast flow path and CZ. Materials occupying the fast flow zones were conservatively assumed to have high conductivities, high diffusion coefficients, and no adsorption (i.e., $\mathrm{K}_{d} \mathrm{~S}=0$ milliliters per gram). [SRS-REG-2007-00002]

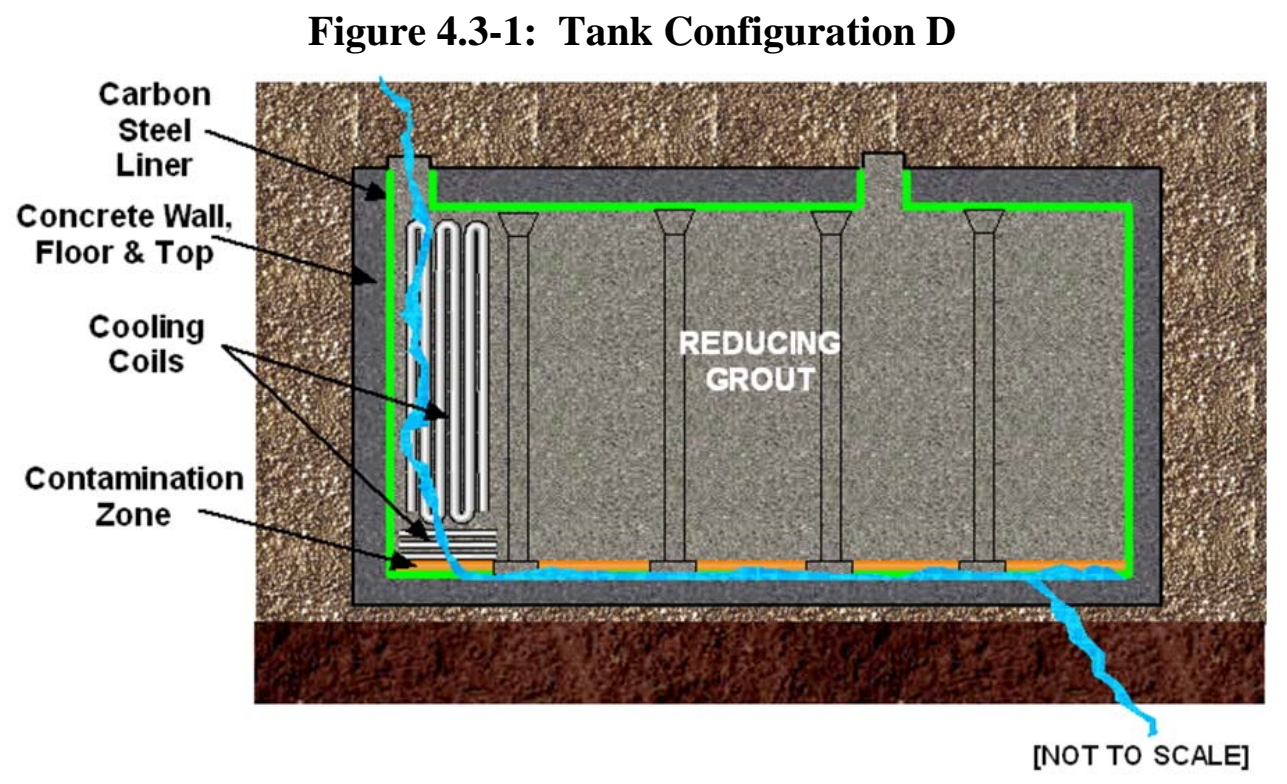

For cementitious material not associated with the fast flow channel, degradation was accelerated over the baseline, with degradation occurring essentially instantaneously at year 500 . The concrete that makes up the walls, the tank grout, and basemat concrete degrade over time (as simulated by increasing hydraulic conductivity). The tank cementitious materials were assumed to begin to degrade at year 500, with degradation occurring essentially instantaneously. [SRSREG-2007-00002]

Configuration D also assumes earlier failure times for the carbon steel liners. After carbon steel liner failure, it was assumed in Tank Configuration D that contaminants begin to leach from the degraded system, via advection, based on changes to the $\mathrm{pH}$, redox potential, and carbonate concentration of the residual contamination in the floor of the tank system. [SRS-REG-200700002]

Equipment used during waste removal activities are not expected to have the requisite shape, placement, and void space to direct flow into the CZ and out of the bottom of the waste tank; therefore, it is unlikely that such conditions would result from the presence of remnant artifacts. Regardless, the dose resulting from Case D does meet performance objectives (i.e., 15 millirem per year is less than 25 millirem per year as shown in Figure 5.6-96 of the FTF-PA), thus providing confidence that the presence of remnant artifacts entombed within the waste tanks will not significantly affect the performance of grout with respect to flow. [SRS-REG-2007-00002] 


\subsection{CONCLUSIONS}

The aforementioned assumptions and analyses indicate that remnant artifacts left in place within the FTF waste tanks are not expected to adversely impact the conclusions asserted within the FTF closure documents. For clarity, Table 5.0-1 explicitly describes the difference between negligible impacts from these remnant artifacts and what should be considered changes to waste tank closure configurations, based upon the discussions in the previous sections.

Table 5.0-1: Matrix of Impact Assessments for Remnant Artifacts in Waste Tanks

\begin{tabular}{|c|c|c|}
\hline $\begin{array}{l}\text { Grout Performance } \\
\text { Feature/Process }\end{array}$ & $\begin{array}{l}\text { Conditions Expected to Provide } \\
\text { Negligible Impacts }\end{array}$ & $\begin{array}{l}\text { Conditions to Evaluate as Potential } \\
\text { Changes to Waste Tank } \\
\text { Configurations }\end{array}$ \\
\hline \multirow{2}{*}{ Waste Tank Stability } & $\begin{array}{l}\text { The grout mix is flowable, pumpable, } \\
\text { and self-leveling to minimize void } \\
\text { space formation. }\end{array}$ & $\begin{array}{l}\text { The grout mix is not flowable, } \\
\text { pumpable, and self-leveling. }\end{array}$ \\
\hline & $\begin{array}{l}\text { Due diligence is exercised to fill the } \\
\text { waste tank with grout, to the extent } \\
\text { practical, reducing void spaces. }\end{array}$ & $\begin{array}{l}\text { Due diligence is not exercised to fill } \\
\text { the waste tank with grout, to the } \\
\text { extent practical, reducing void spaces. }\end{array}$ \\
\hline \multirow{2}{*}{ Reducing Capacity } & $\begin{array}{l}\text { The presence of remnant artifacts } \\
\text { displaces less than 20,000 gallons of } \\
\text { fill grout volume within the waste } \\
\text { tank. }\end{array}$ & $\begin{array}{l}\text { The presence of remnant artifacts } \\
\text { displaces more than } 20,000 \text { gallons of } \\
\text { fill grout volume within the waste } \\
\text { tank. }\end{array}$ \\
\hline & $\begin{array}{l}\text { Due diligence is exercised to limit the } \\
\text { volume of remnant artifacts and } \\
\text { materials, ensuring that a minimal } \\
\text { volume of fill grout will be displaced. }\end{array}$ & $\begin{array}{l}\text { Due diligence is not exercised to limit } \\
\text { the volume of remnant artifacts and } \\
\text { materials, ensuring that a minimal } \\
\text { volume of fill grout will be displaced. }\end{array}$ \\
\hline \multirow{2}{*}{ Flow Modeling } & $\begin{array}{l}\text { The grout conditions are consistent } \\
\text { with the waste tank stability and } \\
\text { reducing capacity assumptions } \\
\text { described within this report. }\end{array}$ & $\begin{array}{l}\text { The grout conditions are not } \\
\text { consistent with the waste tank } \\
\text { stability and reducing capacity } \\
\text { assumptions described within this } \\
\text { report. }\end{array}$ \\
\hline & $\begin{array}{l}\text { The presence of remnant artifacts } \\
\text { does not introduce void spaces that } \\
\text { extend from the top of the waste, } \\
\text { through the fill grout and to the CZ or } \\
\text { floor of the waste tank. }\end{array}$ & $\begin{array}{l}\text { The presence of remnant artifacts } \\
\text { introduces void spaces that extend } \\
\text { from the top of the waste, through the } \\
\text { fill grout and to the } C Z \text { or floor of the } \\
\text { waste tank. }\end{array}$ \\
\hline
\end{tabular}




\subsection{REFERENCES}

C-CLC-F-00462, Tank 18 Telescoping Transfer Pump D\&R, Qualification of TTP and Gould Pump Support on West Riser, Savannah River Site, Aiken, SC, Rev. 0, October 11, 2001.

C-CLC-G-00364, Type I and Type II Waste Tank Cooling Coil to Tank Volume Ratios and Area Ratios, Savannah River Site, Aiken, SC, Rev. 0, March 28, 2007.

C-SPP-F-00055, Furnishing and Delivery of Tank Closure Grout, Savannah River Site, Aiken, SC, Rev. 2, August 29, 2011.

D179154, Waste Removal Facilities Adjusted Dip Tube, Process, Elevation, Details, Savannah River Site, Aiken, SC, Rev. 21 May 30, 1980.

DOE/SRS-WD-2012-001, Basis for Section 3116 Determination for Closure of F-Tank Farm at the Savannah River Site, Savannah River Site, Aiken, SC, DRAFT dated March 12, 2012.

DOE-EIS-0303 ROD, High-Level Waste Tank Closure Final Environmental Impact Statement Record of Decision, Savannah River Site, Aiken, SC, Rev. 0, August 19, 2002.

DOE-EIS-0303, High-Level Waste Tank Closure Final Environmental Impact Statement, Savannah River Site, Aiken, SC, Rev. 0, May 2002.

DPSP-84-17-7, Goslen, A., Tank 19 Salt Removal, Savannah River Site, Aiken, SC, Rev. 0, August 1986.

FTF-TMC-02-015, Tank 18 NE Riser Transfer Pump FL-241-918-WTS-P-12 will be Electrically Disconnected and Temporarily Replace with a Smaller Pump for Dewatering the Tank, Savannah River Site, Aiken, SC, Rev. 0, December 19, 2002.

ISBN: 0-309-59313-1, (Copyright), The State of Development of Waste Forms for Mixed Wastes: U.S. Department of Energy's Office of Environmental Management, Committee on Mixed Wastes, http://download.nap.edu/catalog.php?record_id=9459, National Research Council, Commission on Geosciences, Environment and Resources, 1999, accessed January 26, 2011.

M-CLC-H-02820, Volume and Surface Area Percentages of the Cooling Coils in Type III and Type IIIA Tanks, Savannah River Site, Aiken, SC, Rev. 0, April 17, 2007.

M-CTP-F-00003, Hyche, J., Tank 18 Closure Isolation Plan, Savannah River Site, Aiken, SC, Rev. 2, June 9, 2011.

M-CTP-F-00004, Hyche, J., Tank 19 Closure Isolation Plan, Savannah River Site, Aiken, SC, Rev. 1, June 9, 2011.

PNNL-11968, Performance Evaluation of the PITBULL Pump for the Removal of Hazardous Waste, Savannah River Site, Aiken, SC, Rev. 0, September 30, 1998.

PNNL-12168, Powell, M.R., Evaluation of Flygt Mixers for Application in Savannah River Site Tank, Summary of Test Results Phase A, B, and C Testing, Savannah River Site, Aiken, SC, Rev. 0, April 1999.

S5-2-2489, Waste Evaporator Feed Facilities Riser Insert Arrangement Tank 18, Savannah River Site, Aiken, SC, Rev. 30, July 8, 1975. 
SRNL-STI-2011-00564, Tank 18 and 19-F Tier 1A Equipment Fill Mock Up Test Summary, Savannah River Site, Aiken, SC, Rev. 0, December 14, 2011.

SRNL-STI-2011-00592, Tanks 18 and 19-F Equipment Grout Fill Material Evaluation and Recommendations, Savannah River Site, Aiken, SC, Rev. 0, January 26, 2012.

SRR-CWDA-2010-00003, Industrial Wastewater Closure Module for the Liquid Waste Tanks 18 and 19, Savannah River Site, Aiken, SC, Rev. 2, January 2012.

SRR-CWDA-2010-00124, Tank 18/Tank 19 Special Analysis for the Performance Assessment for the F-Tank Farm at the Savannah River Site, Savannah River Site, Aiken, SC, Rev. 0, February 2012.

SRR-CWDA-2010-00147, Tier 1 Closure Plan for the F-Area Waste Tank Systems at the Savannah River Site, Savannah River Site, Aiken, SC, Rev. 0.

SRR-CWDA-2011-00015, F-Tank Farm Tanks 18 and 19 DOE Manual 435.1-1 Tier 2 Closure Plan Savannah River Site, Savannah River Site, Aiken, SC, Rev. 0.

SRR-CWDA-2011-00054, Comment Response Matrix for United States Nuclear Regulatory Commission Staff Comments on the Draft Basis for Section 3116 Determination and Associated Performance Assessment for the F-Tank Farm at the Savannah River Site, Savannah River Site, Aiken, SC, Rev. 1, June 2011.

SRR-LWE-2010-00175, Tanks 18 and 19 Internal Equipment Evaluation, Savannah River Site, Aiken, SC, Rev. 0, September 23, 2010.

SRR-LWE-2010-00318, Grout Strategy for Tanks 18 and 19 Closure, Savannah River Site, Aiken, SC, Rev. 0, March 9, 2010.

SRS-REG-2007-00002, Performance Assessment for the F-Tank Farm at the Savannah River Site, Savannah River Site, Rev. 1, March 31, 2010.

WSRC-RP-2005-01684, Langton, C., Grout Placement Requirements for SRS Class C Tank Residual Waste Forms, Savannah River Site, Aiken, SC, Rev. 0, April 2005.

WSRC-STI-2007-00369, Hydraulic and Physical Properties of Tank Grouts and Base Mat Surrogate Concrete for FTF Closure, Savannah River Site, Aiken, SC, Rev. 0, October 23, 2007.

WSRC-STI-2007-00641, Langton, C.A., Grout Formulations and Properties for Tank Farm Closure, Savannah River Site, Aiken, SC, Rev. 0, November 12, 2007.

WSRC-TR-97-0102, Caldwell, T. B., Tank Closure Reducing Grout, Savannah River Site, Aiken, SC, Rev. 0, April 1997. 